\title{
Production of Oxalic Acid as Influenced by the Application of Organic Residue and Its Effect on Phosphorus Uptake by Wheat (Triticum aestivum L.) in an Inceptisol of North India
}

\author{
M. L. Dotaniya $\cdot$ S. C. Datta $\cdot$ D. R. Biswas $\cdot$ \\ H. M. Meena $\cdot$ Kuldeep Kumar
}

Received: 9 January 2013/Revised: 7 November 2013/ Accepted: 12 December 2013/Published online: 17 September 2014

(C) The Author(s) 2014. This article is published with open access at Springerlink.com

\begin{abstract}
In the present experiment, an effort was made to explore the possibility of utilizing the organic residue i.e. press mud and bagasse byproducts generated from sugar industries to enhance the $\mathrm{P}$ uptake by different varieties of wheat. The experiment was conducted with five varieties of wheat (HD 2687, HD 2733, HD 2643, HD 2932 and HD 2894) and three levels of organic residue (a mixture of press mud, bagasse and rice straw in 1:1:1 ratio) i.e. 0,5 and $10 \mathrm{t} / \mathrm{ha}$. The addition of organic residue had resulted in the production of oxalic acid by the crop. Higher oxalic acid content $(9.21 \mu \mathrm{g} / \mathrm{g})$ was produced by the variety HD 2687 at 60 days after sowing which resulted in the mobilization of immobile soil $\mathrm{P}$ and helped in increasing the uptake of $\mathrm{P}$ by the crop. The $\mathrm{P}$ uptake increased by about $77 \%$ in the treatment that received the organic residue applied@10 t/ha over control. It was concluded that organic residue from sugar industries could be used to utilize to mobilize the native soil $\mathrm{P}$ to overcome the problem of phosphorus fixation in soils in future.
\end{abstract}

\section{L. Dotaniya ( $\square$ )}

Indian Institute of Soil Science, Nabibagh, Berasia Road, Bhopal 462 038, India

e-mail: mohan30682@gmail.com

\section{S. C. Datta · D. R. Biswas}

Division of Soil Science \& Agricultural Chemistry, IARI, New Delhi, India

H. M. Meena

Central Arid Zone Research Institute, Jodhpur 342 003, India

K. Kumar

Central Soil and Water Conservation Research and Training

Institute, Dehradun, India
Keywords Oxalic acid · Organic residue . Phosphorus uptake . Wheat

\section{Introduction}

Phosphorus has been recognized as an important element in plant nutrition [1]. Considerable research has been done towards defining its chemistry in the soil system. Soils are known to vary widely in their capacity to supply phosphorus to crops, as only a small fraction of it in soil is in available form to crops [2]. In addition to this, phosphorus occurs in very low concentration in soil solution. Its uptake results in a further decrease of its concentration in the soil solution near plant roots [3]. As a result, phosphorus deficiency has become a limiting factor in crop production [4] in agricultural soils worldwide [5]. Phosphatic fertilizers are costly and their efficiency is very low (15-20\%). A major portion of added phosphatic fertilizer is either chemically fixed by $\mathrm{Ca}, \mathrm{Al}, \mathrm{Fe}$ and $\mathrm{Mg}$ or strongly adsorbed on some soil components. Huge amount of organic residues i.e. press mud and bagasse are produced from sugar industries. Their disposal has become a serious problem. Use of press mud and bagasse and crop residue like rice straw, may be useful to overcome the low efficiency of phosphorus. It has been reported that decomposition of sugar rich substance bagasse and press mud release organic acids and play an important role in the mobilization of soil phosphorus [6]. Plant root activity particularly in rhizosphere has been reported to dissolve unavailable form of $\mathrm{P}$ and thereby increase the availability of $\mathrm{P}$ to plant. Exudation of organic acids from roots is considered to be one of the mechanisms for plants to adapt to P-deficiency $[7,8]$. The present study deals with the release of oxalic acid from press mud and bagasse and its effect on phosphorus uptake by different wheat cultivars. 


\section{Materials and Method}

The experimental soil was silt loam in texture belonging to Holambi series, Typic Haplustept. Initial pH, organic carbon, available nitrogen, phosphorus and potassium content were $8.2,0.31 \%, 180,19.2$ and $302 \mathrm{~kg} / \mathrm{ha}$, respectively. The experiment consisted of five wheat varieties (HD 2687, HD 2733, HD 2643, HD 2932 and HD 2894) having different yield potential and genetic characters (Table 1) and three levels of organic residue i.e. 0,5 and 10 t/ha. The organic residue was prepared by mixing equal amounts of press mud, bagasse and chopped rice straw. The organic residue contained $1.1 \% \mathrm{~N}, 0.2 \% \mathrm{P}$ and $0.3 \% \mathrm{~K}$ and was incorporated 15 days before sowing of the crop. Recommended doses of nutrients $\left(120 \mathrm{~kg} / \mathrm{ha} \mathrm{N} ; 60 \mathrm{~kg} / \mathrm{ha} \mathrm{P}_{2} \mathrm{O}_{5}\right.$, $40 \mathrm{~kg} / \mathrm{ha} \mathrm{K}_{2} \mathrm{O}$ ) were supplied to the crop both from organic residue as well as through inorganic sources i.e. urea, single super phosphate and muriate of potash. The crop was raised as per standard agronomic practices. Soil and plant samples were taken at 15 days interval from 30 to 75 days after sowing (DAS). Oxalic acid was extracted with $0.85 M \mathrm{NaF}$ and was determined using high-performance liquid chromatography (HPLC) with buffer solution of $0.05 M \mathrm{KH}_{2} \mathrm{PO}_{4}$ [9]. The crop was harvested at physiological maturity and dried in oven at $70{ }^{\circ} \mathrm{C}$ and analyzed for $\mathrm{P}$ content by yellow color method [10]. The experiment was laid out in a factorial randomized block design and was replicated thrice. The data was analyzed statistically and critical difference was used to compare the treatment means at $5 \%$ probability level [11].

\section{Results and Discussion}

\section{Secretion of Oxalic Acid}

In the present study, different levels of organic residues differed significantly in the release of oxalic acid content in soil. The addition of organic residue increased oxalic acid content from $2.54 \mu \mathrm{g} / \mathrm{g}$ in control to $6.78 \mu \mathrm{g} / \mathrm{g}$ in case of $10 \mathrm{t} / \mathrm{ha}$ (Table 2). It has been reported that the oxalic acid is produced by the soil microbes after decomposition of organic residue either by fermentation of sugar content or starchy materials of the organic residue [12]. Aspergillus niger, one of the most-used $\mathrm{P}$ solubilizers capable of producing significantly high concentrations of citric acid when grown on agro-industrial wastes [13]. The interaction between added organic residues, wheat varieties, crop growth intervals and residue levels was also significant. The interaction between variety and crop residue was maximum $(8.79 \mu \mathrm{g} / \mathrm{g})$ in $10 \mathrm{t} / \mathrm{ha}$ organic residue level in variety $\mathrm{HD} 2687$ and minimum $(1.35 \mu \mathrm{g} / \mathrm{g})$ in $0 \mathrm{t} / \mathrm{ha}$ organic residue level in variety HD 2932 . The interaction between crop growth interval and crop residue was maximum $(7.59 \mu \mathrm{g} / \mathrm{g})$ in case of $10 \mathrm{t} / \mathrm{ha}$ level at 75 DAS against $(1.41 \mu \mathrm{g} / \mathrm{g})$ in control (Table 3). Increased secretion of oxalic acid with increase in crop growth interval has also been reported earlier [14]. It is largely accepted that up to $20-30 \%$ of total carbon assimilated by higher plants is released in the rhizosphere as diverse exudates including $\mathrm{CO}_{2}$ respired [15]. Varieties also had a significant effect on secretion of oxalic acid in soil. The highest secretion of oxalic acid was $(6.53 \mu \mathrm{g} / \mathrm{g})$ as seen in HD 2894 and lowest $(3.41 \mu \mathrm{g} / \mathrm{g})$ in the variety HD 2932. Maximum oxalic acid content $(9.21 \mu \mathrm{g} / \mathrm{g})$ was observed at 60 DAS in variety HD 2687 and minimum $(1.98 \mu \mathrm{g} / \mathrm{g})$ in HD 2932 with 45 DAS (Table 4). The interaction among the varieties, organic residue and time interval was also found to be significant (Table 5). The highest oxalic acid content was recorded in HD 2687 at 60 DAS in control and at 30 DAS at 10 t/ha organic residues. Genetic characteristics of varieties affect physiological appearance as well as biochemical reactions in plants up to a certain limit only [16].

\section{Phosphorus Uptake}

The addition of organic residues significantly increased $\mathrm{P}$ uptake by wheat varieties (Table 6). About $77 \%$ increase

Table 1 Potential yield and genetic characters of the varieties

\begin{tabular}{|c|c|}
\hline Variety & Characteristics \\
\hline HD 2687 & $\begin{array}{l}\text { It also called Shresth. Released by IARI New Delhi, Timely sown variety. Irrigated conditions of NWPZ region. It is bread } \\
\text { wheat variety suitable for North Western Plains Zone, normal sown. The average yield varies } 38.2-41.9 \mathrm{q} / \mathrm{ha}\end{array}$ \\
\hline HD 2733 & $\begin{array}{l}\text { Bread wheat, suitable for North Eastern Plains Zone under normal sowing condition. The average yield from varies } \\
40-42 \mathrm{q} / \mathrm{ha}\end{array}$ \\
\hline HD 2643 & $\begin{array}{l}\text { Bread wheat, suitable for North Eastern Plains Zone under late sowing condition. The average yield varies from } \\
39.5-41.3 \mathrm{q} / \mathrm{ha}\end{array}$ \\
\hline HD 2932 & $\begin{array}{l}\text { It also called wheat PUSA } 111 \text {. It proved to be the most widely adapted and stable variety in the entire area falling in the } \\
\text { central and peninsular parts of the country and exhibits high magnitude of adult plant resistance to leaf and stem rust } \\
\text { diseases. The average yield varies from } 42-43.3 \mathrm{q} / \mathrm{ha}\end{array}$ \\
\hline HD 2894 & High yielding variety for NCR Delhi. It is developed by IARI New Delhi. Average yield is $5.2 \mathrm{t} / \mathrm{ha}$ \\
\hline
\end{tabular}


Table 2 Secretion of oxalic acid content $(\mu \mathrm{g} / \mathrm{g})$ by wheat varieties affected by different levels of organic residue

\begin{tabular}{|c|c|c|c|c|}
\hline \multirow[t]{2}{*}{ Variety } & \multicolumn{3}{|c|}{ Organic residue (t/ha) } & \multirow[t]{2}{*}{ Mean } \\
\hline & 0 & 5 & 10 & \\
\hline HD 2687 & 2.28 & 8.19 & 8.79 & 6.42 \\
\hline HD 2733 & 2.76 & 5.46 & 5.88 & 4.71 \\
\hline HD 2643 & 2.01 & 3.03 & 6.96 & 3.99 \\
\hline HD 2932 & 1.35 & 4.29 & 4.59 & 3.42 \\
\hline HD 2894 & 4.32 & 7.02 & 8.22 & 6.51 \\
\hline Mean & 2.54 & 5.59 & 6.78 & \\
\hline $\operatorname{LSD}(p<0.05)$ & Variety $=2.58$ & Organic residue $=2.01$ & Variety $\times$ Organic residue $=4.47$ & \\
\hline$S E_{d}$ & 1.30 & 1.01 & 2.26 & \\
\hline
\end{tabular}

Table 3 Secretion of oxalic acid content $(\mu \mathrm{g} / \mathrm{g})$ by different varieties of wheat at different time interval as affected by different level of organic residue

\begin{tabular}{|c|c|c|c|c|}
\hline \multirow[t]{2}{*}{ DAS } & \multicolumn{3}{|c|}{ Organic residue (t/ha) } & \multirow[t]{2}{*}{ Mean } \\
\hline & 0 & 5 & 10 & \\
\hline 30 & 3.45 & 7.29 & 6.57 & 5.76 \\
\hline 45 & 4.56 & 3.21 & 6.93 & 4.89 \\
\hline 60 & 5.97 & 3.78 & 5.97 & 5.25 \\
\hline 75 & 1.41 & 3.36 & 7.59 & 4.14 \\
\hline Mean & 3.84 & 4.41 & 6.78 & \\
\hline $\operatorname{LSD}(p<0.05)$ & $\mathrm{DAS}=\mathrm{NS}$ & Organic residue $=2.01$ & DAS $\times$ Organic residue $=3.03$ & \\
\hline$S E_{d}$ & - & 1.01 & 1.53 & \\
\hline
\end{tabular}

Table 4 Secretion of oxalic acid content $(\mu \mathrm{g} / \mathrm{g})$ by different varieties of wheat at different intervals

\begin{tabular}{llllr}
\hline Variety & DAS & & & \\
\cline { 2 - 5 } & 30 & 45 & 60 & Mean \\
\hline HD 2687 & 6.21 & 6.72 & 9.21 & 3.54 \\
HD 2733 & 8.10 & 3.66 & 3.63 & 3.39 \\
HD 2643 & 2.04 & 5.58 & 4.80 & 3.57 \\
HD 2932 & 4.41 & 1.98 & 4.14 & 3.70 \\
HD 2894 & 8.13 & 6.54 & 4.44 & 3.41 \\
Mean & 5.76 & 4.89 & 5.25 & 6.53 \\
$L S D(p<0.05)$ & Variety $=2.58$ & DAS $=$ NS & Variety $\times$ DAS $=3.99$ & 4.14 \\
$S E_{d}$ & 1.30 & - & 2.01 & \\
\hline
\end{tabular}

in $\mathrm{P}$ uptake was observed when organic residue was applied@10 t/ha over control. The P uptake was 18.2, 22.5 and $32.4 \mathrm{~kg} \mathrm{P} / \mathrm{ha}$ in 0,5 and $10 \mathrm{t} / \mathrm{ha}$ organic residue level, respectively. The release of low molecular weight organic acid anions from plant roots has been hypothesized to be involved in enhancing nutrient acquisition from the rhizosphere [17]. Most of the evidence has come from the growth of plants in hydroponic culture where under nutrient deficiency roots release greater quantity of organic acid anions into the external medium [18]. Decomposition of organic residue released different types of organic acids, which act as a mobilizer of soil native P. The oxalic acid secreted by wheat crop as well as the acid that is produced during the decomposition of organic residue convert the inorganic phosphorus to plant available $\mathrm{P}$ in soil solution and enhance the P uptake in crop plants [19]. However, the importance of the chelating ability of organic acids in comparison to their acidifying ability is still under debate 
Table 5 Production of oxalic acid content $(\mu \mathrm{g} / \mathrm{g})$ in soil affected by organic residue levels, varieties and different time intervals

\begin{tabular}{|c|c|c|c|c|c|c|c|c|c|c|c|c|}
\hline \multirow[t]{4}{*}{ Variety } & \multicolumn{12}{|c|}{ Organic residue $(\mathrm{t} / \mathrm{ha})$} \\
\hline & \multicolumn{4}{|l|}{0} & \multicolumn{4}{|l|}{5} & \multicolumn{4}{|l|}{10} \\
\hline & \multicolumn{4}{|l|}{ DAS } & \multicolumn{4}{|l|}{ DAS } & \multicolumn{4}{|l|}{ DAS } \\
\hline & 30 & 45 & 60 & 75 & 30 & 45 & 60 & 75 & 30 & 45 & 60 & 75 \\
\hline HD 2687 & 2.97 & 13.29 & 18.32 & 0.54 & 2.46 & 3.51 & 0.92 & 2.22 & 13.16 & 3.37 & 8.39 & 7.87 \\
\hline HD 2733 & 4.23 & 1.05 & 4.26 & 0.79 & 11.99 & 4.01 & 4.43 & 2.35 & 7.35 & 5.95 & 3.16 & 7.07 \\
\hline HD 2643 & 0.65 & 1.46 & 4.66 & 1.26 & 2.84 & 2.68 & 3.82 & 2.76 & 2.59 & 12.59 & 5.93 & 6.72 \\
\hline HD 2932 & 2.71 & 0.43 & 1.42 & 0.86 & 7.12 & 0.93 & 6.31 & 2.79 & 3.35 & 4.59 & 4.71 & 5.75 \\
\hline HD 2894 & 5.93 & 6.50 & 1.17 & 3.66 & 11.99 & 4.92 & 4.39 & 6.72 & 6.45 & 8.18 & 7.73 & 10.58 \\
\hline$L S D(p<0.05)$ & & & & & & 6.79 & & & & & & \\
\hline$S E_{d}$ & & & & & & 3.43 & & & & & & \\
\hline
\end{tabular}

Table 6 Effect of different levels of organic residue and varieties of wheat on P uptake $(\mathrm{kg} / \mathrm{ha})$

\begin{tabular}{llll}
\hline Variety & \multicolumn{2}{l}{ Organic residue (t/ha) } & Mean \\
\cline { 2 - 4 } & 0 & 5 & 10 \\
\hline HD 2687 & 18.2 & 21.5 & 27.4 \\
HD 2733 & 19.4 & 19.5 & 31.2 \\
HD 2643 & 17.2 & 23.8 & 31.9 \\
HD 2932 & 17.6 & 24.1 & 32.3 \\
HD 2894 & 18.7 & 23.4 & 39.1 \\
Mean & 18.2 & 22.5 & 32.4 \\
$L S D(p<0.05)$ & Variety $=1.9$ & Organic residue $=1.4$ & 23.3 \\
$S E_{d}$ & 0.96 & 0.71 & 1.62 \\
\hline
\end{tabular}

[20]. Citrate is usually considered as the most powerful organic anions, next to oxalate ions [16] and malate ions [21]. In the present study, the different varieties also differed significantly in their P uptake. Maximum P uptake was recorded in case of variety HD 2894 and minimum in case of variety HD 2687, whereas variety HD 2643 and variety HD 2932 were statistically at par. The interaction effect between organic residue levels and varieties for $\mathrm{P}$ uptake was also significant. Maximum $\mathrm{P}$ uptake (39.1 kg P/ha) was recorded in case of $10 \mathrm{t} / \mathrm{ha}$ organic residue with variety HD 2894 and minimum (17.2 kg P/ha) in case of 0 t/ha organic residue with variety HD 2643. It has been reported that phosphorus uptake depends upon the genetic potential of the varieties [16] as well as concentration of phosphorus in solution [22-24].

In conclusion, the present results suggest that the phosphorus uptake could be enhanced by the combined application of byproduct of sugar industries i.e., press mud and bagasse in combination with rice straw, along with $\mathrm{P}$ fertilizers to increase the P uptake and there by crop yield.

Acknowledgments The authors are thankful to Dr. L. M. Shukla, Dr. Deopal, Division of Soil Science \& Agricultural Chemistry for their valuable guidance during research; Dr. Prem Dureja, Division of Agricultural Chemicals, Indian Agricultural Research Institute, New Delhi for her guidance in the activities related to organic acid determination. The much needed help by Dr. S. Ramana, Indian Institute of Soil Science, Bhopal, is highly appreciated.

Open Access This article is distributed under the terms of the Creative Commons Attribution License which permits any use, distribution, and reproduction in any medium, provided the original author(s) and the source are credited.

\section{References}

1. Taiz L, Zeiger E (1998) Plant physiology. Inc Publishers Massachusetts, USA

2. Reddy DD, Rao AS, Rupa TR (2000) Effects of continuous use cattle manure and fertilizer phosphorus on crop yields and soil organic phosphorus in a Vertisol. Biores Technol 75(2):113-118

3. Bhat KS, Nye PH, Baldwin JP (1976) Diffusion of phosphorus to plant roots in soil: the concentration distance profile in the rhizosphere of root with root hairs in a low P soil. Plant Soil 44:63-72

4. Vashista P, Chaudhary N, Sharma CB (2006) Plant protein tyrosine phosphatases: an overview. Proc Natl Acad Sci India Sect B Biol Sci 76(3):207-215 
5. Schneider KD, Van Straaten P, Mira de Orduna R, Glasauer S, Trevors J, Fallow S, Smith PS (2010) Comparing phosphorus mobilization strategies using Aspergillus niger for the mineral dissolution of three phosphate rocks. J Appl Microbiol 108:366-374

6. Wei LL, Chen CR, Xu ZH (2009) The effect of low-molecularweight organic acids and in organic phosphorus concentration on the determination of soil phosphorus by the molybdenum blue reaction. Biol Fertil Soils 45:775-779

7. Chen CR, Condron LM, Xu ZH (2008) Impacts of grassland afforestation with coniferous trees on soil phosphorus dynamics and associated microbial processes. Rev Ecol Manage 255:396-409

8. McDowell RW, Condron LM, Stewart I (2000) An examination of potential extraction methods to assess plant-available organic phosphorus in soil. Biol Fertil Soils 44:707-716

9. Kraffezyk I, Trolldenier K (1979) Extraction of soluble organic acids from nutrient solution culture of maize. Releases Ger Soil Sci Soc 29:385-389

10. Jackson ML (1967) Soil chemical analysis. Prentice Hall of India Pvt Ltd, New Delhi

11. Gomez KA, Gomez A (1983) Statistical procedures for agricultural research. Wiley, New York

12. Kubicek CP, Rohr M (1986) Citric acid fermentation. CRC Critic Rev Biotech 3:331-373

13. Vassilev N, Vassileva M (2003) Biotechnological solubilization of rock phosphate on media containing agro-industrial wastes. Appli Microbiol Biotechanol 61:435-440

14. Ishikawa S, Adu-Gyamfi JJ, Nakamura T, Yoshihara T, Watanabe T, Wagatsuma T (2002) Genotypic variability in phosphorus solubilizing activity of root exudates by pigeonpea grown in lownutrient environments. Plant Soil 245(1):71-81

15. Helal HM, Sauerbeck D (1989) Carbon turnover in the rhizosphere. Z. pflanzenern Bodenk 152:211-216

16. Schlesinger WH (1997) Biogeochemistry: an analysis of global change. Academic Press, USA

17. Ryan PR, Dong B, Watt M, Kataoka T, Delhaize E (2000) Strategies to isolate transporters that facilitate organic anion efflux from plant roots. Plant Soil 248:61-69

18. Jones DL (1998) Organic acids in the rhizosphere-a critical review. Plant Soil 205:25-44

19. Dotaniya ML (2012) Crop residue management in rice-wheat cropping system. Lap Lambert Academic Publisher, Germany

20. Subbarao GV, Ae N, Otani T (1997) Genotypic variation in ironand aluminum-phosphate solubilizing activity of pigeonpea root exudates under $\mathrm{P}$ deficient conditions. Soil Sci Plant Nutri 43:295-305

21. Bolan NS, Naidu R, Mahimairaja S, Baskaran S (1994) Influence of low-molecular-weight organic acids on the solubilization of phosphates. Biol Fertil Soils 18:311-319

22. Dakora FD, Phillips DA (2002) Root exudates as mediators of mineral acquisition in low-nutrient. Plant Soil 245:35-47

23. Dotaniya ML, Datta SC, Biswas DR, Meena BP (2013) Effect of solution phosphorus concentration on the exudation of oxalate ions by wheat (Triticum aestivum L.). Proc Natl Acad Sci India Sect B Biol Sci. doi:10.1007/s40011-012-0153-7

24. Dotaniya ML, Datta SC (2013) Impact of bagasse and press mud on availability and fixation capacity of phosphorus in an Inceptisol of north India. Sugar Tech. doi:10.1007/s12355-013-0264-3 